\title{
The Effectiveness of Vocational Education and Training on Sustainable Development with Particular Focus on Magunje Vocational Training Centre, Hurungwe District, Mashonaland West Province
}

\author{
Eric S. M. S. Makura ${ }^{1}$, Musitaffa Mweha $^{2}$, Elizabeth Chikwiri ${ }^{3}$ \\ ${ }^{1}$ Womenee ${ }^{\text {ee }}$ University in Africa, Dept. of Education and Development Studies, Mt. Pleasant, Harare, Zimbabwe \\ ${ }^{2}$ International Labour Organisation, Harare, Zimbabwe
}

${ }^{3}$ Women ees University in Africa, Faculty of Social Sciences and Gender Development Studies, Mt. Pleasant, Harare, Zimbabwe

\begin{abstract}
This study sought to determine the impact of Vocational Education and Training on Sustainable Development provided by Magunje Centre. The researchers were drawn to the study, for establishment of such centres by the Government throughout the country has not resulted in noticeable improvement in the livelihoods of the ruralites. The study found that lack of funding for training materials, tools, equipment, and other related needs were the reasons for the failure of the Centre's training to transform the livelihoods of the ruralites. The study observed that for the Centre to have more impact, it needed to have a clear vision, strategic planning, initiatives, and effective implementation as well as adequate Government funding.
\end{abstract}

Keywords: Vocational Education and Training; Sustainable Development; Livelihoods; Economic and Social Well-Being; Curriculum.

\section{Introduction}

When Zimbabwe attained Independence in 1980, after the indigenes had been under the yoke of rabid racist colonial domination and exploitation [1] for almost a century, the Black Majority Government under the leadership of Robert Gabriel Mugabe, moved fast in trying to redress the inherited obnoxious racial imbalances. One of the measures taken by the Government was to empower the indigenes with vocational skills which they had for long been deliberately denied by the minority White Settler Oligarchy. In 1984, the Government repealed the Vocational Education and Training Act of 1978 [2] which was meant to benefit only the minority White Settlers, and passed the Manpower Planning and Development Act [3] to effect the policy. The Act replaced the Manpower Development and Training Authority, with the National Manpower Advisory Council. It provided for the establishment of Government Vocational Education and Training (VET) Centres, registration of private training institutions, and established the Zimbabwe Manpower Development Fund (ZIMDEF).

This study was concerned with determining the impact of VET on sustainable development in rural areas provided by Magunje Vocational Training Centre (VTC), Hurungwe District, Mashonaland West Province. The researchers were intrigued into carrying out the study, for despite the establishment of such Centres by the Government throughout the country, there appeared to be no noticeable improvement in the livelihoods of the ruralites. The two interrelated questions which intrigued the researchers were, whether ruralites who received training at such Centres were indolent in utilising the acquired skills, or the training offered by these Centres was inadequate.

\section{Literature Review}

United Nations Economic Commission for Africa (UNECA) (2005) [4] states that economic stagnation in Africa has resulted massive unemployment and accompanying abject poverty. The establishment of VET Centres would greatly help Africa to solve the rampant unemployment problem it is encountering. By having people equipped with skills, such Centres would enable the Graduates to engage in entrepreneurial activities, thereby improving economic and social well-being, and creating more employment opportunities for the unskilled populace. Entrepreneurial activities carried out by the VET Graduates would not only result in the production of more goods and services, but equally, would lead to such produced goods and services being sold at affordable prices than would otherwise be the case.

2.1. Zimbabwe Government Policy on Vocational Education and Training

According to the 1981 Zimbabwe Government Policy Statement, Growth with Equity [5], Government was determined to expand the economy, and improve the economic and social well-being of the people. The Policy Statement guaranteed security of employment. To expand the economy, Government needed to provide VET. Consequently, in 1984, the Government repealed the racist Vocational Education and Training Act of 1978 [6], and 


\section{International Journal of Science and Research (IJSR) \\ ISSN (Online): 2319-7064 \\ Index Copernicus Value (2013): 6.14 | Impact Factor (2014): 5.611}

replaced it with the Manpower Planning and Development Act [7] to effect the Policy. The Policy aimed to provide at least one VET Centre in every Province, and established the ZIMDEF to fund the Centres

However, the determination of the Government to redress racial imbalances in every sector of the economy inherited from the colonial era, particularly access to education and health services, resulted in Government facing serious liquidity problems. Desperate, in 1990, the Government reluctantly accepted free-market policy prescriptions, known as The Economic Structural Adjustment Programme (ESAP) [8], from the Bretton Woods Financial Institutions. Instead of enabling the Government to carry on with its noble objectives, ESAP resulted in unprecedented levels of hyperinflation, continuous decline in Gross Domestic Product growth rates, massive devaluation of the currency, low productivity, loss of employment, food shortages, abject poverty, closing of industries and general despondency. To make it worse, when in 2000, the Government tried to democratise the distribution of land through the Fast-Track Land Reform Programme [9], the Western powers swiftly responded by imposing wide-ranging sanctions against the country, which are still in force. In 2009, the Government adopted what is called the Short Term Emergency Recovery Programme (STERP) [10] aimed at meeting worsening economic challenges, as a result of ESAP. However, STERP failed to improve the situation. The ever worsening serious liquidity problems made it difficult for the Government to fund not only VET Centres, but also other various reform programmes.

According to Mambo (2010) [11], structural unemployment worsened from around 50 percent to about 65 percent in 2005. The situation was exacerbated by more than 200,000 school leavers who could not find formal employment. In the writeres opinion, ESAP resulted in a marked decline in enrolments at VET Centres. Zunguze (2003) [12] opines that the welfare gains of the 1980s were eroded as budgetary allocations to social sectors decreased. He goes on to state that extreme poverty increased significantly during 1990s with an estimated $35 \%$ of the population living below the poverty datum line in 1995 compared to about $26 \%$ in 1990 .

\subsection{Human Capital Theory}

In the view of Schuller et al. (2002) [13], human capital needs to be seen as knowledge and skills individuals gain to enhance their productivity in the labour market and also to function better in various other aspects of their lives. Thus, VET effectively contributes to human capital formation and accumulation. Alam (2007) [14] observes that Human Capital Theory enables the analysis of labour market. He argues that investment in education and training greatly benefits the individual and society as a whole. Such investments, on the one hand, enables the individual to have a better career path, better earnings, and better quality of life, on the other hand, provides society with skilled workforce. Echoing the same view, Fagerlind and Saha (1989) [15] state that education and training raises the productivity of workers, and increases their lifetime earning capacity. However, Colin (1999) [16] opines that technical and vocational education
(TVE) can certainly play a crucial role in development, provided that the policy makers provide adequate funding, and the Centres have adequate qualified teachers. Alam (2007) [17] observes that Governments tend to see the importance of skilled labour only when the economy is expanding.

\subsection{The Concept of Sustainable Development}

World Commission on Environment and Development (1987:43) [18] states that, "The development that meets the generation "s needs of the present without compromising the ability of future generations to meet their needs." Baumann (2011) [19] opines that inter-generational dimensions of sustainable development call for the reconciliation of economic development with environmental and social needs. Kates et al (2005) [20] argue that the malleability of the concept ,sustainable development ${ }^{\text {ee }}$ allows it to remain an open, dynamic, and evolving idea that can be adapted to fit these very different situations and contexts across space and time. In the opinion of Gibson et al (2007) [21], sustainable development is not a state to be achieved, but rather a set of principles to apply and processes to follow. Drexhage and Murphy (2010) [22] state that sustainable development calls for a convergence between the three pillars of economic development, social equity, and environmental protection. According to UNESCO (2002) [23], cooperation of everyone is needed for applying the principles and for following the processes that give birth to a culture of sustainability. Haertel (2011:1) [24] could not have made a more perceptive observation when he commented that, "The debate on sustainable development is aligned with the endeavour to shape societal and economic development in such a way as to enable [environmentally] liveable conditions for the majority of the population." Thus, it is cogent to argue that sustainable development emphasizes the need for a balance among and the integration of, economic, environmental and social concerns.

\subsection{TVE and Sustainable Development}

The Centre for Technical and Vocational Education and Training (2009) [25] states that skills training is crucial for competitiveness of national economic systems, labour market productivity, poverty reduction, and the promotion of sustainable development. According to Osmani (2003) [26], sustained economic growth is vitally important for sustained poverty reduction. In the view of Alam (2007) [27], TVE, including formal education, public awareness and training, is a process by which human beings and societies are enabled to realise their potential. King and Palmer (2008) [28] argue that full and productive employment and decent work are one link between economic growth and poverty reduction. Baumann (2011) [29] observes that VET reduces poverty by developing capabilities among ruralites in adopting climate change mitigation strategies. Kombe (2003) [30] observes that TEV training prepares people for the world of work. It is therefore, not unreasonable to argue that TEV is vitally important for the promotion of sustainable development.

\subsection{Role of Ruralites in VET implementation}




\section{International Journal of Science and Research (IJSR) \\ ISSN (Online): 2319-7064}

Index Copernicus Value (2013): 6.14 | Impact Factor (2014): 5.611

According to Viertel (2002) [31], ruralites need to be actively involved in the implementation of VET. He argues that unless they are actively involved, they would not appreciate the importance of the skills to be gained from the training. Thus, it is crucial to avoid a Top-Down Approach in implementing VET.

\subsection{Benefits of VET to Ruralites}

Kombe (2003) [32] observes that VET is crucial in the development of any economy. According to IIEP (2006:1) [33], "Providing training in vocational skills plays an important role in equipping young people and adults with the skills required for work and social integration." "In a rapidly changing environment", IIEP (2006:3) [34] states, "strengthening the skills of rural communities can reduce their vulnerability and help them to cope with new economic and social conditions...Vocational schools can revitalize a region, increase incomes, reduce instability of livelihoods, enhance community participation, and give voice to the poor and needy." In the view of Schuller et al. (2002) [35], vocational training benefits both an individual and communities. Akyeampong (2002) [36] points out that TVE is important not only for its economic contribution but also for its cultural, social and political contribution. The International Labour Organization (ILO) (2001) [37] states that TVE is important in developing human capital. The World Bank (1991) [38] stresses that for TVE to effectively promote development, the curriculum must be relevant, welltimed, and linked to local and global demand. Thus, VET is crucial in the improvement of the economic and social wellbeing of the ruralites.

\subsection{Challenges in the implementation of VET in Rural Areas}

While VET is crucial in the development of rural areas, the world over, it tends to encounter various challenges. Seng (1996) [39] states that in Singapore, VET is constantly adjusted in order to meet changes in the formal education system and industry. According to Smawfield (2005) [40], while VET is a supply-side intervention, putting newly acquired skills to use and establishing viable income generating activities depend on the demand. He goes on to state that, in Malawi, tailors, carpenters and tinsmiths find it extremely difficult to put their skills into profitable use, for there is simply no demand. The World Bank (1990) [41] states that, providing relevant VET in Bangladesh requires a lot of money, for its per capita, is too low. In the opinion of Lauglo and Lillis (1988) [42], VET requires expensive items such as equipment, tools, training consumables, training manuals, support system and personnel which are not easily met. Imoro and Nti (2009) [43] state that people who underwent VET in Northern Ghana found themselves unable to put their skills into use for the Government failed to provide them with start-up capital and equipment.

In Zimbabwe, between June 2010 and November 2011, the Portfolio Committee on Women Affairs, Youth, Gender and Community Development conducted field visits to 14 VTC in seven provinces, to establish challenges encountered by Centres.
In its First Report [44], the Committee noted the following challenges:

- Tuition fees charged were clearly unaffordable to majority of candidates;

- Infrastructure at VET Centres was inadequate;

- Inadequate Government funding;

- Most VET Centres had inadequate water supply;

- Low morale among lecturers and support staff;

- Inadequate electricity supply; and

- Inadequate vehicles;

\section{Findings}

This study unearthed the following Findings:

- Ruralites in Magunje District were keen to acquire skills provided at Magunje VTC.

- Skills acquired from Magunje VTC have not enabled the graduates to meaningfully improve their economic and social well-being as well as that of their communities.

- Magunje VTC graduates have not been able to establish income generating projects due to lack of start-up fluid capital and equipment.

- Most households stated that they encouraged young people to try and acquire skills provided at Magunje VTC.

- Inadequate electricity and water supply for almost 4 years greatly affected the operations of Magunje VTC.

- Magunje VTC had inadequate training materials and obsolete training equipment;

- Lack of agriculture courses in the Curriculum of Magunje VTC has resulted in a loss of interest in its training.

- Non-existence of an Advisory Board at Magunje VTC has resulted in the Centre being isolated from the local community, business and donor communities.

- Failure to actively involve the local Authority, Hurungwe Rural District Council has resulted in the local Authority not assisting the Centre.

- Lack of boarding facilities has made it difficult for ruralites living far away from Magunje VTC not enrolling for skills training.

\section{Conclusions}

From the Findings of this study, certain salient points may be made. Ruralites are keen to acquire skills provided at Magunje VTC. However, they are rather disappointed that the Centre does not have agriculture on its Curriculum, a Course which would have greatly benefited majority of the ruralites. Since most of the Graduates from the Centre are from poor families, Government needs to make determined effort and try to provide them with adequate start-up fluid capital and equipment. This would enable the graduates to expand their entrepreneurial activities, thereby creating more employment opportunities in the District for the unskilled ruralites, and producing goods and services that would be sold at affordable prices than would otherwise be the case. For the Centre to have more impact in the District, it needs to have adequate funding from the Government. The Centre needs to actively involve the Local Authority, Magunje Rural District Council, in its activities, if it is to have more impact 


\section{International Journal of Science and Research (IJSR) \\ ISSN (Online): 2319-7064}

Index Copernicus Value (2013): 6.14 | Impact Factor (2014): 5.611

in the District. Since the Centre caters for a large District, it is imperative that there be boarding facilities for candidates from faraway places.

\section{Notes}

[1] For a detailed analysis of White Settler rabid racist colonial domination and exploitation in Zimbabwe, see Eric S.M.S. Makura: Southern Rhodesia: The Making and Implementation of the Two-Pyramid Policy, $1890-$ 1948: A Study in Discrimination and Exploitation, Ph.D. Thesis, Dalhousie University Centre of African Studies (DUCAS), 1981.

[2] See Rhodesia: Vocational Education and Training Act, Salisbury, Govt. Printers, 1978.

[3] See Zimbabwe: Manpower Planning and Development Act, Harare, Govt. Printers, 1984.

[4] See United Nations Economic Commission for Africa: Meeting the United Nations Educational, Scientific and Cultural Organization, 2005.

[5] See Growth with Equity: An Economic Policy Statement, Harare, Govt. Printers, 1981.

[6] See Foot Note 2.

[7] See Foot Note 3.

[8] See Economic Structural Adjustment Programme, Harare, Govt. Printers, 1991.

[9] See Fast-Track Land Reform Programme, Harare, Govt. Printers, 2000.

[10] See Zimbabwe: Medium Term Plan, January 2010 December 2015, Harare, Govt. Printers, 2015; African Development Bank: Zimbabwe Short-Term StrategyConcept Note, Regional Department, South Region A, 2009.

[11] See Mambo, N.M: Situational Analysis and Institutional Mapping for Skills for Youth Employment and Rural Development in Zimbabwe, ILO, 2010.

[12] See Zunguze, M: Zimbabwe: Progress Report on the Implementation of the Platform for Action 1995-2003, 2003.

[13] See Schuller, T. et al.: Learning, continuity and change in adult life. London: Institute of Education, 2002.

[14] See Alam, G.M.: Private HE in Bangladesh: the impact on $H E$ governance and legislation, Unpublished $\mathrm{PhD}$ Thesis, University of Nottingham, 2007.

[15] See Fagerlind, I., \& Saha, L.J. (1989): Education and national development: A comparative perspective, Oxford, Oxford University Press, 2007.

[16] See Colin, N.P.: „Technical and vocational education for the twenty first century'. Prospect, 29 (1), 29-36, 1999.

[17] See Foot Note 14.

[18] See World Commission on Environment and Development: Our Common Future. Oxford: Oxford University Press, 1987.

[19] See Baumann, A.: ETF Position Paper: Sustainable Development and Education and Training, Turin, European Training Foundation, 2011.

[20] See Kates R.W., Parris T.M., Leiserowitz A.A.: „What is Sustainable Development? Goals, Indicators, Values, and Practice"e, Environment: Science and Policy for Sustainable Development, Vol. 47, 3, 2005, pp. 8-21.
[21] See Gibson, R. B., Hassan, S., Holtz, S., Tansey, J., and Whitelaw, G.: Sustainability assessment: Criteria and processes. Sterling, Earthscan, 2007.

[22] See Drexhage. J. and Murphy. D.: Sustainable Development: From Brundtland to Rio 2012. Background Paper prepared for consideration by the High Level Panel on Global Sustainability at its first meeting, International Institute for Sustainable Development (IISD). 19 September 2010. New York, UN, 2007.

[23] See United Nations Educational, Scientific and Cultural Organization: Education for sustainability: From Rio to Johannesburg: lessons learnt from a decade of commitment, 2002.

[24] See Haertel, M.: TVET for Sustainable Development: Policy-Making Strategies and Project Experiences: German Federal Institute for Vocational Education and Training, 2011.

[25] See UNESCO-UNEVOC: Report of the International Expert Consultation Meeting on Technical and Vocational Education: Centre for Technical and Vocational Education and Training Bonn, 12-13, January 2009.

[26] See Osmani, S. : Exploring the Employment Nexus: Topics in Employment and Poverty, Geneva, UNDP/ILO, 2003.

[27] See Foot Note 14

[28] See King, K. and Palmer, R.: „Planning for Technical and Vocational Skills Developmente, Fundamentals of Educational Planning, No.94, Paris, IIEP, 2010.

[29] See Baumann, A.: ETF Position Paper: Sustainable Development and Education and Training, Turin, European Training Foundation, 2011.

[30] See Kombe. A.M: „Technical Education and Vocational Training as a Tool for Sustainable Development ${ }^{e c}$, Access to Education and Training through Open and Distance learning, Lusaka, 2003.

[31] See Viertel, V.: Successful Development Practices in Non-formal Adult Training in the Light of Persisting Poverty, 2002.

[32] See Foot Note 30

[33] See IIEP: Building Skills for Poverty Reduction: Newsletter, Vol. XXIV, No,. 3, July - Sept., 2006.

[34] Ibid.

[35] See Foot Note 13

[36] See Akyempong, A.K.: Vocationalization on secondary education in Ghana. Washington, DC, World Bank, 2002.

[37] See ILO: Revised recommendation concerning technical and vocational education, 2001.

[38] See World Bank: Vocational and technical education and training. Washington, DC, World Bank, 1991.

[39] See Seng. S.L.: Dynamics and Challenges of a Vocational Training System: The Singapore Experience, ITE, 1996.

[40] See Smawfield. D.: Vocational Training Handbook: $A$ Practical Guide to Planning and Implementation of Vocational Training Programmes with Refugees in a Developing Country Context, 2005.

[41] See World Bank: Bangladesh vocational and technical education. Washington, DC, World Bank, 1990. 


\section{International Journal of Science and Research (IJSR) \\ ISSN (Online): 2319-7064}

Index Copernicus Value (2013): 6.14 | Impact Factor (2014): 5.611

[42] See Lauglo, J., \& Lillis, K.: „Vocationalization in international perspective', Comparative Education Review, 34(3), 1988, pp. 411-414.

[43] See Imoro.B. and Nti .K.O. : „Sustainable Vocational Skills Development for Poverty Reduction in Northern Ghana', Journal of Sustainable Development in Africa, Vol. 10, No.4, 2009.

[44] See First Report of the Portfolio Committee on Women Affairs, Youth, Gender, and Community Development on the Challenges and Constrains affecting the Operations of Vocational Training Centres in Zimbabwe, Government Printers, 2012.

\section{References}

[1] African Development Bank: Zimbabwe Short-Term Strategy-Concept Note, Regional Department, South Region A, 2009.

[2] Akyempong, A.K.: Vocationalization on secondary education in Ghana. Washington, DC, World Bank, 2002.

[3] Alam, G.M.: Private HE in Bangladesh: the impact on $H E$ governance and legislation, Unpublished $\mathrm{PhD}$ Thesis, University of Nottingham, 2007.

[4] Baumann, A.: ETF Position Paper: Sustainable Development and Education and Training, Turin, European Training Foundation, 2011.

[5] Baumann, A.: ETF Position Paper: Sustainable Development and Education and Training, Turin, European Training Foundation, 2011.

[6] Colin, N.P.: „Technical and vocational education for the twenty first century'. Prospect, 29(1), 29-36, 1999.

[7] Drexhage. J. and Murphy. D.: Sustainable Development: From Brundtland to Rio 2012. Background Paper prepared for consideration by the High Level Panel on Global Sustainability at its first meeting, International Institute for Sustainable Development (IISD). 19 September 2010. New York, UN, 2007.

[8] Economic Structural Adjustment Programme, Harare, Govt. Printers, 1991.

[9] Fagerlind, I., \& Saha, L.J. (1989): Education and national development: A comparative perspective, Oxford, Oxford University Press, 2007.

[10] Fast-Track Land Reform Programme, Harare, Govt. Printers, 2000.

[11]First Report of the Portfolio Committee on Women Affairs, Youth, Gender, and Community Development on the Challenges and Constrains affecting the Operations of Vocational Training Centres in Zimbabwe, Government Printers, 2012.

[12] Gibson, R. B., Hassan, S., Holtz, S., Tansey, J., and Whitelaw, G.: Sustainability assessment: Criteria and processes. Sterling, Earthscan, 2007.

[13] Growth with Equity: An Economic Policy Statement, Harare, Govt. Printers, 1981.

[14] Haertel, M.: TVET for Sustainable Development: PolicyMaking Strategies and Project Experiences: German Federal Institute for Vocational Education and Training, 2011.

[15] IIEP: Building Skills for Poverty Reduction: Newsletter, Vol. XXIV, No,. 3, July - Sept., 2006.
[16] ILO: Revised recommendation concerning technical and vocational education, 2001.

[17] Imoro.B. and Nti .K.O.: „Sustainable Vocational Skills Development for Poverty Reduction in Northern Ghana', Journal of Sustainable Development in Africa, Vol. 10, No.4, 2009.

[18] Kates R.W., Parris T.M., Leiserowitz A.A.: „What is Sustainable Development? Goals, Indicators, Values, and Practicee, Environment: Science and Policy for Sustainable Development, Vol. 47, 3, 2005, pp. 8-21.

[19]King, K. and Palmer, R.: ,Planning for Technical and Vocational Skills Developmente, Fundamentals of Educational Planning, No.94, Paris, IIEP, 2010.

[20] Kombe. A.M: „Technical Education and Vocational Training as a Tool for Sustainable Development ${ }^{e c}$, Access to Education and Training through Open and Distance learning, Lusaka, 2003.

[21]Lauglo, J., \& Lillis, K.: „Vocationalization in international perspective', Comparative Education Review, 34(3), 1988, pp. 411-414.

[22] Makura, E.M.S. : Southern Rhodesia: The Making and Implementation of the Two-Pyramid Policy, $1890-$ 1948: A Study in Discrimination and Exploitation, Ph.D. Thesis, Dalhousie University Centre of African Studies (DUCAS), 1981.

[23] Mambo, N.M: Situational Analysis and Institutional Mapping for Skills for Youth Employment and Rural Development in Zimbabwe, ILO, 2010.

[24] Osmani, S. : Exploring the Employment Nexus: Topics in Employment and Poverty, Geneva, UNDP/ILO, 2003.

[25]Rhodesia: Vocational Education and Training Act, Salisbury, Govt. Printers, 1978.

[26] Schuller, T. et al.: Learning, continuity and change in adult life. London: Institute of Education, 2002.

[27] Seng. S.L.: Dynamics and Challenges of a Vocational Training System: The Singapore Experience, ITE, 1996.

[28] Smawfield. D.: Vocational Training Handbook: $A$ Practical Guide to Planning and Implementation of Vocational Training Programmes with Refugees in a Developing Country Context, 2005.

[29] UNESCO-UNEVOC: Report of the International Expert Consultation Meeting on Technical and Vocational Education: Centre for Technical and Vocational Education and Training Bonn, 12-13, January 2009.

[30] United Nations Economic Commission for Africa: Meeting the United Nations Educational, Scientific and Cultural Organization, 2005.

[31] United Nations Educational, Scientific and Cultural Organization: Education for sustainability: From Rio to Johannesburg: lessons learnt from a decade of commitment, 2002.

[32] Viertel, V.: Successful Development Practices in Nonformal Adult Training in the Light of Persisting Poverty, 2002.

[33] World Bank: Bangladesh vocational and technical education. Washington, DC, World Bank, 1990.

[34] World Bank: Vocational and technical education and training. Washington, DC, World Bank, 1991.

[35] World Commission on Environment and Development: Our Common Future. Oxford: Oxford University Press, 1987. 


\section{International Journal of Science and Research (IJSR) \\ ISSN (Online): 2319-7064}

Index Copernicus Value (2013): 6.14 | Impact Factor (2014): 5.611

[36]Zimbabwe: Manpower Planning and Development Act, Harare, Govt. Printers, 1984.

[37]Zimbabwe: Medium Term Plan, January 2010 December 2015, Harare, Govt. Printers, 2015.

[38]Zunguze, M: Zimbabwe: Progress Report on the Implementation of the Platform for Action 1995-2003, 2003.

Volume 5 Issue 2, February 2016

www.ijsr.net 